\title{
Spread of odontogenic infections in the elderly: Prevalence and characteristic multidetector CT findings
}

\author{
Ichiro Ogura*1,2, Norihito lizuka ${ }^{2}$, Marie Ishida ${ }^{2}$, Eri Sawada ${ }^{2}$, Takashi Kaneda ${ }^{2}$ \\ ${ }^{1}$ Department of Radiology, The Nippon Dental University Niigata Hospital, Niigata, Japan \\ ${ }^{2}$ Department of Radiology, Nihon University School of Dentistry at Matsudo, Chiba, Japan
}

Received: December 15, 2016

Accepted: February 15, 2017

Online Published: February 16, 2017

DOI: $10.5430 /$ ijdi.v4n1p28

URL: https://doi.org/10.5430/ijdi.v4n1p28

\begin{abstract}
Purpose: To analyze spread of odontogenic infections in the elderly, especially the prevalence and characteristic multidetector computed tomography (MDCT) findings.

Materials and methods: Ninety-seven patients with odontogenic infection who underwent 64-row MDCT were evaluated in this study. The study patients comprised 31 elderly patients ( $\geq 60$ years) and 66 adults ( $<60$ years). Age, gender, location of causal tooth, and spread of odontogenic infections with MDCT were analyzed.

Results: The elderly patients (74.2\%) had higher ratio with female compared to the adults (57.6\%). The buccal space (93.5\%) was the most common spread of odontogenic infections for the elderly patients, followed by the masticator space (54.8\%) and submandibular space $(45.2 \%)$, whereas the buccal space $(97.0 \%)$ was the most common spread of odontogenic infections for the adults, followed by submandibular space $(65.2 \%)$ and masticator space (51.5\%). Logistic multivariate regression analysis for odontogenic infections in the elderly demonstrated that the gender (odds ratio $=3.462, P=.024$ ) and submandibular space (odds ratio $=0.168, P=.013$ ) were significant variable.

Conclusions: The study showed the prevalence and characteristic MDCT findings of spread of odontogenic infections in the elderly.
\end{abstract}

Key Words: Computed tomography, Odontogenic infections, Fascial spaces, Elderly, Head and neck

\section{INTRODUCTION}

Odontogenic infections can extend to adjacent fascial spaces, if not properly controlled. ${ }^{[1,2]}$ Odontogenic infections in elderly with systemic diseases were the most important predictive factors in deep neck infections. ${ }^{[3]}$ These infections were grave and potentially life-threatening infection, ${ }^{[3,4]}$ because the extension should be very grave and rapid, and lead to critical airway obstruction. ${ }^{[5-7]}$
Realization of the anatomy in head and neck region is essential for the diagnosis and treatment of odontogenic infections, because the fascia is an effective barrier to the infection expansion. ${ }^{[8,9]}$ Computed tomography (CT) can very contribute to evaluation on the spread of odontogenic infections. ${ }^{[10-12]}$

In recent years, multidetector computed tomography (MDCT) has become a standard imaging modality of maxillofacial lesions because of the exquisite sensitivity of this

\footnotetext{
*Correspondence: Ichiro Ogura; Email: ogura@ngt.ndu.ac.jp; Address: Department of Radiology, The Nippon Dental University Niigata Hospital, 1-8 Hamaura-cho, Chuo-ku, Niigata, Niigata 951-8580, Japan.
} 
imaging technique. ${ }^{[13,14]}$ Furthermore, MDCT enable realization of the region and spread of abscesses to masticator space derived from severe odontogenic infection. ${ }^{[15-17]}$ The present study analyzed spread of odontogenic infections in the elderly, especially the prevalence and characteristic MDCT findings.

\section{MAterials AND Methods}

Ninety-seven patients with odontogenic infection who underwent 64-row MDCT were evaluated in this study. The study patients comprised 31 elderly patients ( $\geq 60$ years) and 66 adults ( $<60$ years). The diagnosis of odontogenic infection was diagnosed from the clinical course of patient. Surgical drainage and/or tooth extraction of origin of infection were performed in all patients after CT imaging. Clinical signs and symptoms of all cases were reduced after antibiotic treatment.

Imaging was scanned by a 64-row MDCT (Aquilion 64, Toshiba Medical Systems, Otawara, Japan) by protocol at our hospital of the oral and maxillofacial lesions. In this study, CT imaging was performed without use of contrast agent because immediate treatment is necessary. The two oral and maxillofacial radiologists evaluated the region of an abscess and cellulitis to the different components of the buccal space, submandibular space, sublingual spaces, masticator space and parapharyngeal space using soft-tissue algorithm CT images. ${ }^{[18,19]}$

The data collected included age, gender, location of causal tooth, and spread of odontogenic infections with MDCT were compared with elderly and adults using logistic multivariate regression analysis.

\section{RESUltS}

Table 1 shows comparison between elderly and adult patients with odontogenic infections. The elderly patients had lower ratio with male in compared to the adults $(25.8 \% \mathrm{vs}$. $42.4 \%)$ and multiple spaces involved (71.0\% vs. $77.3 \%)$. Regarding location of facial space, the buccal space (93.5\%) was the most common spread of odontogenic infections for the elderly patients, followed by masticator space (54.8\%), whereas buccal space $(97.0 \%)$ was the most common spread of odontogenic infections in the adults, followed by submandibular space $(65.2 \%)$.

Table 2 shows the profiles of fascial space involvement by odontogenic infection in 97 patients. The buccal space ( 8 patients: $25.8 \%$ ) was the most frequent in 31 patients in the elderly, followed by the buccal, submandibular and masticator spaces (5 patients: $16.1 \%$ ), and buccal and masticator spaces (5 patients: 16.1\%). In 66 patients in the adults, the buccal, submandibular and masticator spaces (17 patients: $25.8 \%$ ) were the most frequent, followed by buccal space (15 patients: $22.7 \%$ ), and buccal and submandibular spaces (11 patients: $16.7 \%)$.

Table 1. Comparison between elderly and adult patients with odontogenic infections

\begin{tabular}{|c|c|c|c|}
\hline Parameter & Elderly & Adults & Total \\
\hline Number of patients & 31 (32.0\%) & $66(68.0 \%)$ & $97(100 \%)$ \\
\hline \multicolumn{4}{|l|}{ Age (years) } \\
\hline Mean $\pm S D$ & $70.7 \pm 7.8$ & $42.3 \pm 10.4$ & $51.4 \pm 16.4$ \\
\hline Range & $60-87$ & $21-59$ & $21-87$ \\
\hline \multicolumn{4}{|l|}{ Gender } \\
\hline Male & $8(25.8 \%)$ & $28(42.4 \%)$ & $36(37.1 \%)$ \\
\hline Female & $23(74.2 \%)$ & $38(57.6 \%)$ & $61(62.9 \%)$ \\
\hline \multicolumn{4}{|l|}{ Location of causal tooth } \\
\hline Maxilla & $6(19.4 \%)$ & $13(19.7 \%)$ & $19(19.6 \%)$ \\
\hline Mandible & $25(80.6 \%)$ & $53(80.3 \%)$ & $78(80.4 \%)$ \\
\hline \multicolumn{4}{|c|}{ Spread of odontogenic infections with MDCT } \\
\hline \multicolumn{4}{|c|}{ Number of spaces involved } \\
\hline Single & $9(29.0 \%)$ & $15(22.7 \%)$ & $24(24.7 \%)$ \\
\hline Multiple & $22(71.0 \%)$ & $51(77.3 \%)$ & $73(75.3 \%)$ \\
\hline \multicolumn{4}{|c|}{ Location of fascial space } \\
\hline Buccal space & $29(93.5 \%)$ & $64(97.0 \%)$ & $93(95.9 \%)$ \\
\hline Submandibular space & $14(45.2 \%)$ & $43(65.2 \%)$ & $57(58.8 \%)$ \\
\hline Sublingual spaces & $5(16.1 \%)$ & $6(9.1 \%)$ & $11(11.3 \%)$ \\
\hline Masticator space & $17(54.8 \%)$ & $34(51.5 \%)$ & $51(52.6 \%)$ \\
\hline Parapharyngeal space & $8(25.8 \%)$ & $15(22.7 \%)$ & $23(23.7 \%)$ \\
\hline
\end{tabular}

Note. SD: standard deviation; MDCT: multidetector computed tomography.

Table 2. Profiles of fascial space involvement by odontogenic infection in 97 patients

\begin{tabular}{llll}
\hline Fascial space with MDCT & $\begin{array}{l}\text { Elderly } \\
\mathbf{n = 3 1}\end{array}$ & $\begin{array}{l}\text { Adults } \\
\mathbf{n}=\mathbf{6 6}\end{array}$ & $\begin{array}{l}\text { Total } \\
\mathbf{n}=\mathbf{9 7}\end{array}$ \\
\hline BS & $8(25.8 \%)$ & $15(22.7 \%)$ & $23(23.7 \%)$ \\
BS, SMS, MS & $5(16.1 \%)$ & $17(25.8 \%)$ & $22(22.7 \%)$ \\
BS, SMS & $2(6.5 \%)$ & $11(16.7 \%)$ & $13(13.4 \%)$ \\
BS, MS & $5(16.1 \%)$ & $7(10.6 \%)$ & $12(12.4 \%)$ \\
BS, SMS, MS, PPS & $3(9.7 \%)$ & $6(9.1 \%)$ & $9(9.3 \%)$ \\
BS, SLS, SMS, MS, PPS & $1(3.2 \%)$ & $4(6.1 \%)$ & $5(5.2 \%)$ \\
BS, SMS, PPS & $0(0 \%)$ & $3(4.5 \%)$ & $3(3.1 \%)$ \\
BS, PPS & $1(3.2 \%)$ & $1(1.5 \%)$ & $2(2.1 \%)$ \\
BS, MS, PPS & $2(6.5 \%)$ & $0(0 \%)$ & $2(2.1 \%)$ \\
SLS, SMS & $1(3.2 \%)$ & $1(3.2 \%)$ & $2(2.1 \%)$ \\
BS, SLS, SMS, MS & $1(3.2 \%)$ & $0(0 \%)$ & $1(1.0 \%)$ \\
BS, SLS, SMS, PPS & $1(3.2 \%)$ & $0(0 \%)$ & $1(1.0 \%)$ \\
SLS & $1(3.2 \%)$ & $0(0 \%)$ & $1(1.0 \%)$ \\
SLS, SMS, PPS & $0(0 \%)$ & $1(1.5 \%)$ & $1(1.0 \%)$ \\
\hline
\end{tabular}

Note. MDCT: multidetector computed tomography; BS: buccal space; SMS: submandibular space; SLS: sublingual space; MS: masticator space; PPS: parapharyngeal space.

Logistic multivariate regression analysis for odontogenic infections in the elderly demonstrated that the gender (odds 
ratio $=3.462, p=.024$ ) and submandibular space (odds ratio $=0.168, p=.013$ ) were significant variable (see Table 3 ).

Table 3. Logistic multivariate regression analysis of patients with odontogenic infections in the elderly

\begin{tabular}{llll}
\hline & Odds ratio & 95\% CI & P value \\
\hline Gender & 3.462 & $1.174-10.204$ & .024 \\
Location of causal tooth & 2.214 & $0.550-8.911$ & .263 \\
Spread of odontogenic infections with MDCT & \\
Number of spaces involved & 0.858 & $0.137-5.379$ & .870 \\
Buccal space & 0.295 & $0.014-6.114$ & .430 \\
Submandibular space & 0.168 & $0.041-0.687$ & .013 \\
Sublingual spaces & 2.046 & $0.317-13.190$ & .451 \\
Masticator space & 1.851 & $0.466-7.354$ & .382 \\
Parapharyngeal space & 1.603 & $0.457-5.625$ & .461 \\
\hline
\end{tabular}

Note. MDCT: multidetector computed tomography; CI: confidence interval.
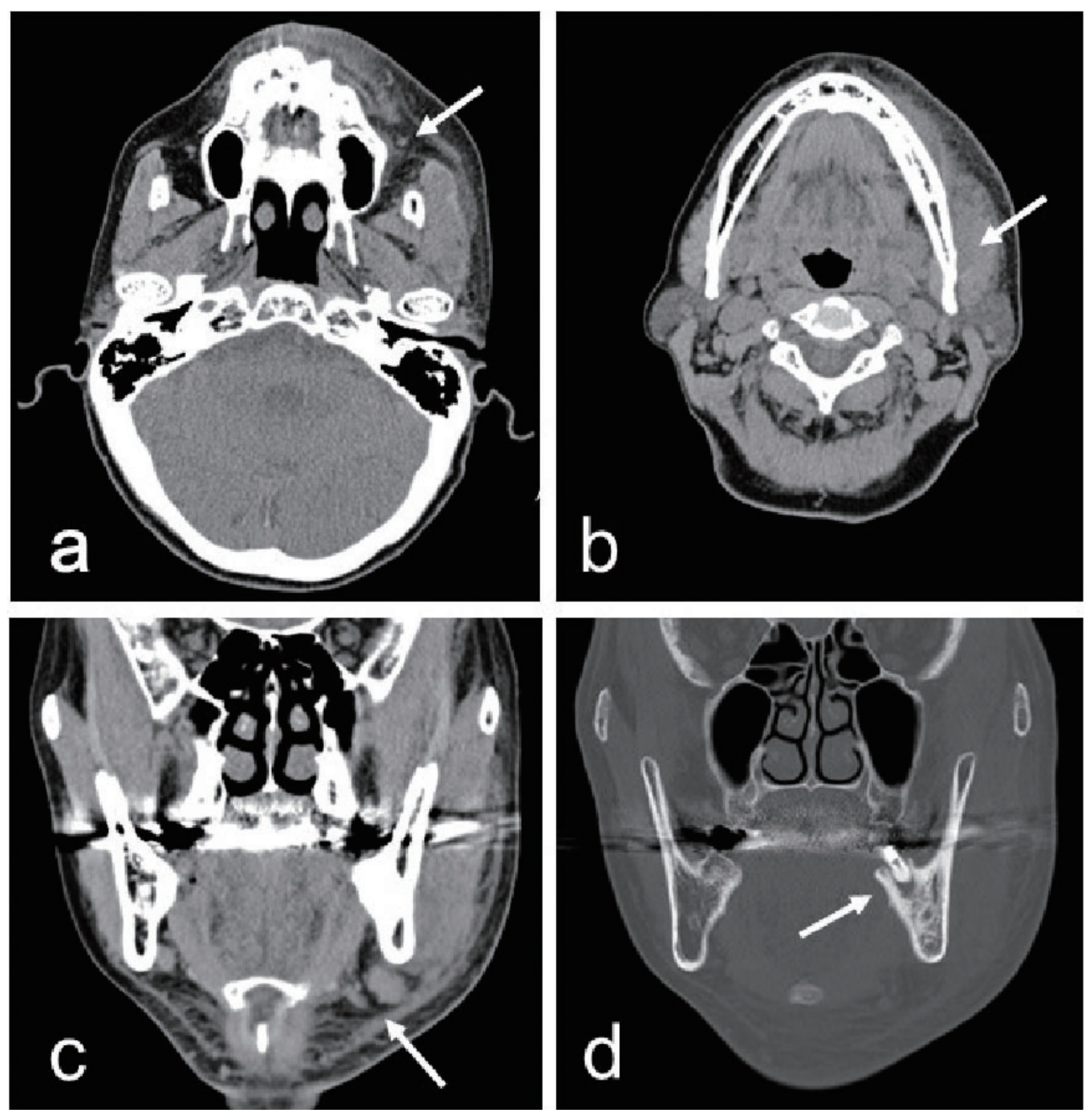

Figure 1. A 68-year-old female with odontogenic infections. a. Axial soft-tissue algorithm CT image demonstrates the spread of odontogenic infections in buccal space (arrow); b. Axial soft-tissue algorithm CT image demonstrates the spread of odontogenic infections in masticator space (arrow); c. Coronal soft-tissue algorithm CT image demonstrates the spread of odontogenic infections in submandibular space (arrow); d. Coronal bone-algorithm CT image demonstrates mandibular periapical lesion (the second molar teeth, arrow) 

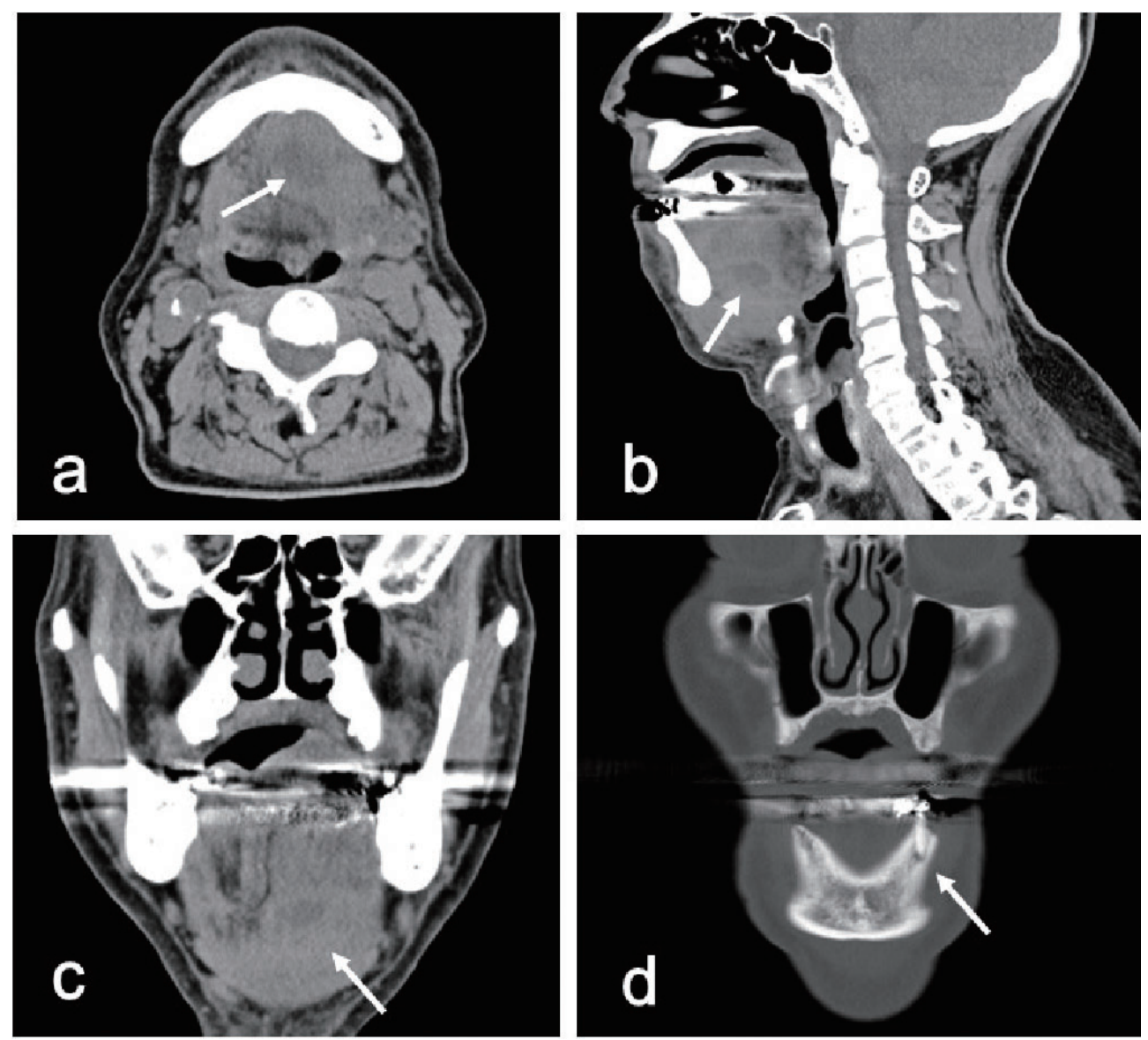

Figure 2. A 82-year-old male with odontogenic infections. a. Axial soft-tissue algorithm CT image demonstrates the spread of odontogenic infections in sublingual space (arrow); b, c. Sagittal and coronal soft-tissue algorithm CT image to better advantage shows the spread of odontogenic infections in sublingual space (arrow); d. Coronal bone-algorithm CT image demonstrates mandibular periapical lesion (the first premolar teeth, arrow)

Furthermore, the authors indicated that buccal space and masticator space was the most common spread in odontogenic infections for the elderly patients, whereas the buccal space and submandibular space were the most common spread of odontogenic infections in the adults. Obayashi et al. ${ }^{[11]}$ showed that changes in the alveolar cortical plates were found more frequently in the labial and buccal side than in the palatal side, and masticator space changes were predominantly seen in the patients with infection caused by maxillary molars. Ohshima et al. ${ }^{[12]}$ showed that the cortical the cortical thickness was thinner on the lingual side than the buccal side, and that the extension of odontogenic infection from mandibular teeth is more likely to occur on the lingual side than the buccal side. Alotaibi et al. ${ }^{[20]}$ showed that the frequency of deep neck space infection was significantly higher in patients with mandibular odontogenic infection $(29 \%)$ than in those with maxillary odontogenic infection (7\%). Our data indicated that the frequency of odontogenic infections was higher in cases of mandibular odontogenic infection $(80.4 \%)$ than in those of maxillary odontogenic infection (19.6\%). Moghimi et al. ${ }^{[21]}$ indicated that infection of maxillary teeth most commonly extension to buccal space, whereas infection originating in mandible mostly extension to the submandibular, pterygomandibular, and buccal spaces. We consider that these anatomical character should explain inflammation easily expansion to buccal space and masticator space in the elderly.

Regarding multiple spaces, in the present study, $75.3 \%$ of all patients with odontogenic infection showed involvement in multiple spaces. Furthermore, the authors showed that, compared to the adults, the elderly patients had lower ratio with multiple spaces involved $(71.0 \%$ vs. $77.3 \%)$. Chi et al. ${ }^{[22]}$ showed that compared to the adult (aged between 18 and 65) group with deep neck infection, the elderly (older than 65 years of age) group had higher ratio with multiple spaces involved (53.1\% vs. 30.2\%). Ariji et al. ${ }^{[10]}$ showed that the odontogenic infection pathway through the mylohyoid muscle or sublingual space was observed most frequently in patients with submandibular space involvement. 
Schuknecht et al. ${ }^{[15]}$ report that medial masticator space abscesses tend to display early extra-spatial parapharyngeal space and soft palate, because the parapharyngeal space is linked to the submandibular space inferiorly. In the present study, buccal space was the most frequent in the elderly, followed by the buccal, submandibular and masticator spaces, and buccal and masticator spaces. The potential spaces that can become involved in an odontogenic infection depends on two factors - the relation of the tooth roots to the thinnest alveolar bone plate (which determines the site of perforation from the bone) and the related muscles (which determine the location of the closest fascial space). This means that the upper molars will initially develop only buccal space infections and the lower teeth will produce submandibular space, masticator buccal or sublingual space infections depending on the associated anatomical factors. Therefore, the buccal space is considered to be important in odontogenic infection, because in this space is often accompanied by changes in other spaces.

In this study, odontogenic infections in the elderly patients had higher ratio with female compared to the adults. We consider that the age and gender distribution is closely related to the circumstance of odontogenic infections, because life span is the difference between male and female. Furthermore,
Huang et al. ${ }^{[3]}$ indicated that elderly and associated systemic diseases were the most important predictive factors in deep neck infections. Opitz et al. ${ }^{[23]}$ showed if well-known risk factors are present in patients affected by odontogenic infection appropriate interdisciplinary management should be considered as early as possible. We consider that the relationship between medical conditions and spread of odontogenic infections is important for future studies.

\section{Conclusions}

The study showed the prevalence and characteristic MDCT findings of spread of odontogenic infections in the elderly. These findings can be helpful for medical and surgical management of odontogenic infections in the elderly.

\section{ACKNOWLEDGements}

The authors wish to thank Dr. Makoto Tsuchimochi, Professor, Department of Oral and Maxillofacial Radiology, The Nippon Dental University School of Life Dentistry at Niigata. This work was supported by NDU Grants N-16020.

\section{CONFlicts of InTEREST Disclosure}

We declare no financial support or relationship that may pose conflict of interest.

\section{REFERENCES}

[1] Rega AJ, Aziz SR, Ziccardi VB. Microbiology and antibiotic sensitivities of head and neck space infections of odontogenic origin. J Oral Maxillofac Surg. 2006; 64: 1337-80. PMid:16916672 https ://doi.org/10.1016/j.joms.2006.05.023

[2] Rao DD, Desai A, Kulkarni RD, et al. Comparison of maxillofacial space infection in diabetic and nondiabetic patients. Oral Surg Oral Med Oral Pathol Oral Radiol Endod. 2010; 110: e7-12. PMid:20656528 https://doi.org/10.1016/j.tripleo.2010 .04 .016

[3] Huang TT, Liu TC, Chen PR, et al. Deep neck infection: analysis of 185 cases. Head Neck. 2004; 26: 854-60. PMid:15390207 https://doi.org/10.1002/hed. 20014

[4] Flynn TR, Shanti RM, Levi MH, et al. Severe odontogenic infections, part 1: prospective report. J Oral Maxillofac Surg. 2006; 64: 1093-103. PMid:16781343 https://doi.org/10.1016/j.joms .2006 .03 .015

[5] Larawin V, Naipao J, Dubey SP. Head and neck space infections. Otolaryngol Head Neck Surg. 2006; 135: 889-93. PMid:17141079 https://doi.org/10.1016/j.otohns.2006.07.007

[6] Bassiony M, Yang J, Abdel-Monem TM, et al. Exploration of ultrasonography in assessment of fascial space spread of odontogenic infections. Oral Surg Oral Med Oral Pathol Oral Radiol Endod. 2009; 107: 861-9. PMid:19464659 https://doi.org/10.1016/j.tr ipleo.2009.02.016

[7] Akinbami BO, Akadiri O, Gbujie DC. Spread of odontogenic infections in Port Harcourt, Nigeria. J Oral Maxillofac Surg. 2010; 68:
2472-7. PMid:20633973 https://doi.org/10.1016/j.joms . 2 010.01 .019

[8] Ariji E, Moriguchi S, Kuroki T, et al. Computed tomography of maxillofacial infection. Dentomaxillofac Radiol. 1991; 20: 14751. PMid:1807998 https://doi.org/10.1259/dmfr.20.3.18 07998

[9] Yonetsu K, Izumi M, Nakamura T. Deep facial infections of odontogenic origin: CT assessment of pathways of space involvement AJNR Am J Neuroradiol. 1998; 19: 123-8. PMid:9432169

[10] Ariji Y, Gotoh M, Kimura Y, et al. Odontogenic infection pathway to the submandibular space: imaging assessment. Int J Oral Maxillofac Surg. 2002; 31: 165-9. PMid:12102414 https://doi.org/10.1 054/ijom. 2001.0190

[11] Obayashi N, Ariji Y, Goto M, et al. Spread of odontogenic infection originating in the maxillary teeth: computerized tomographic assessment. Oral Surg Oral Med Oral Pathol Oral Radiol Endod. 2004; 98: 223-31. PMid:15316549 https://doi.org/10.1016/j.triple 0.2004 .05 .014

[12] Ohshima A, Ariji Y, Goto M, et al. Anatomical considerations for the spread of odontogenic infection originating from the pericoronitis of impacted mandibular third molar: computed tomographic analyses. Oral Surg Oral Med Oral Pathol Oral Radiol Endod. 2004; 98: 58997. https://doi.org/10.1016/S1079-2104(04)00507-4

[13] Boeddinghaus R, Whyte A. Current concepts in maxillofacial imaging. Eur J Radiol. 2008; 66: 396-418. PMid:18082349 https : //doi.org/10.1016/j.ejrad.2007.11.019 
[14] Ogura I, Sasaki Y, Kaneda T. Analysis of mandibular condylar and glenoid fossa fractures with computed tomography. Eur Radiol. 2014; 24: 902-6. PMid:24337861 https://doi.org/10.1007/s00330 $-013-3085-6$

[15] Schuknecht B, Stergiou G, Graetz K. Masticator space abscess derived from odontogenic infection: imaging manifestation and pathways of extension depicted by CT and MR in 30 patients. Eur Radiol. 2008; 18: 1972-9. PMid:18418606 https ://doi.org/10.1007/ s00330-008-0946-5

[16] Abdel Razek AA. Computed tomography and magnetic resonance imaging of lesions at masticator space. Jpn J Radiol. 2014; 32: 123-37. PMid:24500138 https://doi .org/10.1007/s11604-0 14-0289- $\mathrm{x}$

[17] Wabik A, Hendrich BK, Nienartowicz J, et al. Odontogenic inflammatory processes of head and neck in computed tomography examinations. Pol J Radiol. 2014; 79: 431-8. PMid:25436021 https://doi.org/10.12659/PJR. 890808

[18] Hardin CW, Harnsberger HR, Osborn AG, et al. Infection and tumor of the masticator space: CT evaluation. Radiology. 1985; 157: 413-7. PMid:4048449 https://doi.org/10.1148/radiology.157.2. 4048449
[19] Curtin HD. Separation of the masticator space from the parapharyngeal space. Radiology. 1987; 163: 195-204. PMid:3823435 https://doi.org/10.1148/radiology.163.1.3823435

[20] Alotaibi N, Cloutier L, Khaldoun E, et al. Criteria for admission of odontogenic infections at high risk of deep neck space infection. Eur Ann Otorhinolaryngol Head Neck Dis. 2015; 132: 261-4. PMid:26347337 https://doi.org/10.1016/j. anorl. 2015.0 8.007

[21] Moghimi M, Baart JA, Karagozoglu KH, et al. Spread of odontogenic infections: a retrospective analysis and review of the literature. Quintessence Int. 2013; 44: 351-61. PMid:23479578

[22] Chi TH, Tsao YH, Yuan CH. Influences of patient age on deep neck infection: clinical etiology and treatment outcome. Otolaryngol Head Neck Surg. 2014; 151: 586-90. PMid:25037266 https : //doi.org/10.1177/0194599814542589

[23] Opitz D, Camerer C, Camerer DM, et al. Incidence and management of severe odontogenic infections - a retrospective analysis from 2004 to 2011. J Craniomaxillofac Surg. 2015; 43: 285-9. PMid:25555896 https://doi.org/10.1016/j.jcms.2014.12.002 